\title{
Decreased IL-37 expression in hepatocellular carcinoma tissues and liver cancer cell lines
}

\author{
PENG LI $^{1^{*}}$, HONGSHENG GUO ${ }^{1 *}, \mathrm{KUN} \mathrm{WU}^{2,3^{*}}$, LIUDAN SU $^{3}, \mathrm{KAI} \mathrm{HUANG}^{2}, \mathrm{RUIZHI} \mathrm{LAI}^{3}$, ZILIANG DENG $^{1}$, \\ SHUXIAN LI ${ }^{1}$, PING OUYANG ${ }^{4}$, YAN WANG $^{2}$, ZHANGQUAN CHEN $^{3}$, GUANGJI ZHOU $^{1}$ and SEN WANG ${ }^{1,3}$ \\ ${ }^{1}$ Department of Histology and Embryology, Basic Medical College; ${ }^{2}$ Department of Internal Medicine, \\ The Second Clinical Medical College; ${ }^{3}$ Department of Clinical Immunology, Institute of Laboratory Medicine; \\ ${ }^{4}$ Guangdong Provincial Key Laboratory of Medical Molecular Diagnostics, Dongguan Scientific Research Center, \\ Guangdong Medical University, Dongguan, Guangdong 523808, P.R. China
}

Received June 21, 2019; Accepted October 16, 2019

DOI: $10.3892 / \mathrm{ol} .2020 .11393$

\begin{abstract}
The role of IL-37 in cancer is currently largely unknown. The present study aimed to investigate IL-37 expression in hepatocellular carcinoma (HCC), paracancerous tissues (PT) and liver cancer cell lines, and their associations between IL-37 and NF-kB. A total of $65 \mathrm{HCC}$ and 65 PT tissues were collected. The expression of IL-37 and NF- $\mathrm{KB}$ in tissues was detected by immunohistochemistry (IHC) and the data was analyzed using SPSS software. In the in vitro studies, IL-37 gene was transfected into HepG2 and MHCC97H cell lines with Lipofectamine 3000, and the protein regulation of NF- $\kappa B$ by IL-37 was verified by immunofluorescence (IF) and western blotting. In HCC, the positive expression rates of IL-37 and NF-kB were 21.5 and $95.4 \%$, respectively. In PT, strong positive staining of IL-37and weak positive staining of NF- $\kappa \mathrm{B}$ were observed. The normal expression levels of IL-37 and NF- $\kappa B$, the increased IL-37 and decreased NF- $\kappa B$ induced by IL-37 gene transfection were observed through IF in cell lines. In terms of clinical significance, the difference in IL-37 expression between HCC and PT was statistically significant $\left(\chi^{2}=55.05 ; \mathrm{P}<0.001\right)$. IL-37 expression in HCC but not PT was negatively associated with serum AFP $\left(\chi^{2}=6.522 ; \mathrm{P}=0.039\right)$. IL-37 expression in PT was associated with sex $\left(\chi^{2}=13.12\right.$; $\mathrm{P}=0.003)$ and tumor size $\left(\chi^{2}=7.996 ; \mathrm{P}=0.045\right)$. NF- $\mathrm{\kappa B}$ expression in PT was associated with age, sex and BCLC stage. Notably, there was a negative correlation between IL-37 and $\mathrm{NF}-\kappa \mathrm{B}$ in HCC $(\mathrm{r}=-0.277 ; \mathrm{P}=0.029)$ but not in $\mathrm{PT}(\mathrm{P}>0.05)$. IL-37 overexpression downregulated the NF- $\mathrm{KB}$ protein by
\end{abstract}

Correspondence to: Dr Sen Wang, Department of Histology and Embryology, Basic Medical College, Guangdong Medical University, 1 Xincheng Road, Dongguan, Guangdong 523808, P.R. China E-mail: wangsen@gdmu.edu.cn

*Contributed equally

Key words: IL-37, hepatocellular carcinoma, NF-кB, paracancerous tissues, $\alpha$-fetoprotein
$56.50 \%$ in HepG2 cells $(\mathrm{P}<0.05)$ and $30.52 \%$ in $\mathrm{MHCC} 97 \mathrm{H}$ cells $(\mathrm{P}<0.05)$. In conclusion, the expression of IL-37 in HCC and PT was specifically associated with serum AFP and tumor size, respectively. IL-37 expression was negatively correlated with NF- $\mathrm{KB}$ protein expression in HCC tissues and liver cancer cell lines.

\section{Introduction}

Liver cancer, primarily known as hepatocellular carcinoma (HCC), is the fifth most common cancer worldwide. Furthermore, $>780,000$ new cases of liver cancer were estimated worldwide in 2012 (1). Various injury factors, including hepatitis B virus (HBV) infection (2), chronic aflatoxin intake (3) and alcohol consumption (4), could induce long-term chronic inflammation and promote carcinogenesis. Therefore, inflammation and inflammatory pathways play a role in the occurrence and development of liver cancer, indicating that anti-inflammatory cytokines or drugs will be a potential way for the prevention and treatment of liver cancer (5).

The new interleukin anti-inflammatory cytokine IL-37 was first cloned in 2000 and officially named in 2010 (6). IL-37 exerted anti-inflammatory and immunomodulatory effects by inhibiting a variety of pro-inflammatory factors, including IL-6, IL- $1 \alpha$, IL-1 $\beta$ and TNF- $\alpha$ (6). It has been reported that IL-37 can relieve the inflammatory response in a variety of diseases, such as colitis (7), rheumatoid arthritis (8), allergic disease (9), leprosy (10), systemic lupus erythematous (11) and transplantation rejection (12). Certain studies have also demonstrated that IL-37 can protect the liver from ischemia-reperfusion injury (13) and inhibit T cell-dependent liver injury (14). Given the close association between liver inflammation and liver cancer, IL-37 may play a crucial part in the occurrence and development of liver cancer.

The role of IL-37 in liver cancer currently remains unclear. In previous studies, IL-37 has been demonstrated to inhibit the proliferation and invasion of cervical cancer cells through STAT3, and promoted cell apoptosis through Bcl-2-like protein $11(15,16)$. In non-small cell lung cancer and renal cell carcinoma, IL-37 played an anticancer role through STAT3 (17). In gallbladder carcinoma, IL-37 acted as a tumor suppressor by 

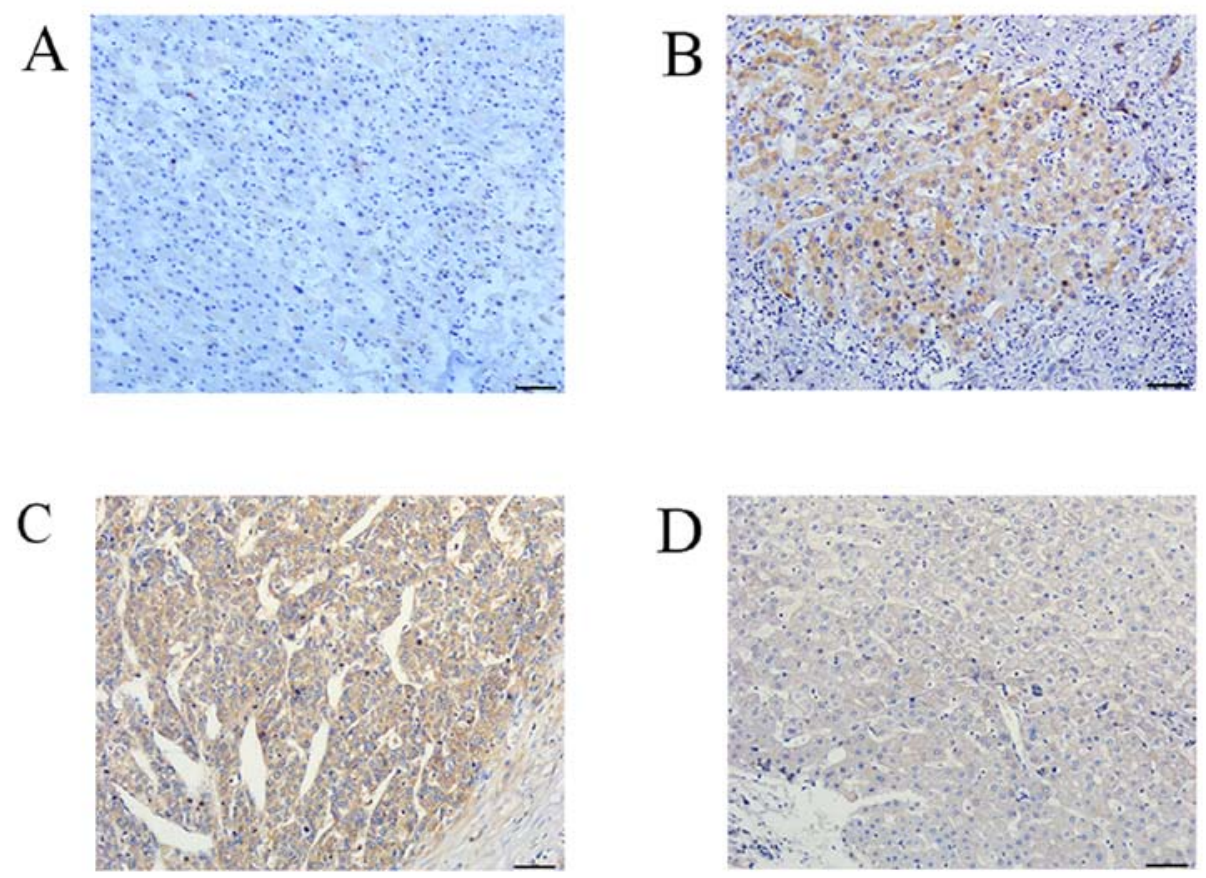

Figure 1. IL-37 and NF- $\mathrm{kB}$ protein expression in HCC and paracancerous tissues. (A) IL-37 expression in HCC tissues. (B) IL-37 expression in paracancerous tissues. (C) NF- $\mathrm{kB}$ expression in HCC tissues. (D) NF- $\mathrm{kB}$ expression in paracancerous tissues. Scale bar, $60 \mu \mathrm{m}$. HCC, hepatocellular carcinoma.

inhibiting cell migration and invasion (18). In another study, IL-37 and CD66b+ TANs (tumor-associated neutrophils) were considered as independent factors for evaluating the prognosis of colorectal cancer (19). In HCC, IL-37 was associated with CD57+ natural killer cells (20). However, to the best of our knowledge, data remain limited in further understanding the role of IL-37 in HCC. NF- $\mathrm{KB}$ functions as not only a transcription factor in the process of inflammation but also an important regulator of tumorigenesis in HCC. The present study focused on the significance of IL-37 and NF- $\mathrm{kB}$ expression in HCC, paracancerous tissues (PT) and liver cancer cell lines. The present study aimed to investigate the expression of IL-37 in hepatocellular carcinoma, paracancerous tissues and liver cancer cell lines, and the association between IL-37 and NF- $\mathrm{kB}$ expression.

\section{Materials and methods}

Specimens. The present study was reviewed and approved by the Medical Ethics Committee of Foshan First People's Hospital, Foshan, China [approval no. L(2016)3]. All patients agreed to the use of their samples in the present study and provided written informed consent. All personal information will be kept confidential and not disclosed. Slices of specimens of 65 HCC and 65 PT ( $2 \mathrm{~cm}$ from tumor tissue) were collected from the Department of the Pathology of Foshan First People's Hospital. Among 65 cases of HCC, there were 51 males and 14 females. Their ages ranged from 16-89, with an average age of $48.8 \pm 10.5$ years, and a median age of 51 years. There were 17 cases of AFP negative $(\leq 8.1 \mathrm{ng} / \mathrm{ml})$ and 28 cases of AFP positive. All subjects were diagnosed with HCC for the first time and did not receive radiotherapy or chemotherapy. Patients with diabetes, autoimmune diseases or other diagnosed serious or chronic inflammatory diseases, including colitis or pneumonia, were excluded from this study.
Materials. Human liver cancer cell lines, HepG2 and MHCC $97 \mathrm{H}$ were purchased from the Cell Bank of Typical Culture Preservation Committee of Chinese Academy of Sciences (Shanghai, China), where the cell lines were authenticated via STR profiling. IL-37 gene (NM_014439) was cloned into a pEZ-M02 vector (Genecopoeia, Inc.) by the manufacturer. Lipofectamine 3000 was purchased from Invitrogen; Thermo Fisher Scientific, Inc. Rabbit anti-human IL-37 (cat.no.ab153889),NF-kB (cat.no.D14E12) and GAPDH primary antibody (cat. no. AB-P-R 001) were obtained from Abcam, Cell Signaling Technology, Inc., and Goodhere Technology, respectively. HRP-labeled goat anti-mouse IgG (cat. no. A0216), HRP-labeled Goat Anti-Rabbit IgG (cat. no. A0208), ECL kit, BCA Protein Quantitative kit, RIPA buffer, SDS-PAGE kit and DAPI staining kit were obtained from Beyotime Biotechnology. PVDF membranes were purchased from EMD Millipore.

Immunohistochemistry (IHC).IHC was performed as described in a previous study (21). Briefly, the paraffin-embedded sections ( $4 \mu \mathrm{m}$ thick) were dewaxed with xylene and rehydrated using decreasing gradient of alcohol (100, 95, 85 and $75 \%$ ). Antigen retrieval was performed under high pressure at $115^{\circ} \mathrm{C}$ for $6 \mathrm{~min}$. The samples were incubated with primary antibodies against IL-37 (1:100) and NF- $\mathrm{KB}$ (1:100) overnight at $4^{\circ} \mathrm{C}$. Samples were visualized following incubation with 3'-diaminobenzidine at room temperature for 30-90 sec. In addition, sections were counterstained with hematoxylin at room temperature for 3-10 min. PBS served as a control instead of the primary antibody.

The following method was used for IHC analysis: Five high-power visual fields (magnification x40; under a light microscope) with a large number of parenchymal cells were randomly selected on each slice. Then, the strong positive, weak positive and negative results were determined by the intensity 
Table I. Expression of IL-37 protein in 65 cases of HCC and paracancerous tissues.

IL-37 expression

\begin{tabular}{|c|c|c|c|c|c|c|c|}
\hline \multirow[b]{2}{*}{ Group } & \multirow[b]{2}{*}{$\mathrm{n}(100 \%)$} & \\
\hline & & - & + & ++ & +++ & $\chi^{2}$ & P-value \\
\hline HCC tissues & 65 & $51(78.5)$ & $12(18.5)$ & $0(0.0)$ & $2(3.1)$ & 55.05 & $<0.001$ \\
\hline Paracancerous tissue & 65 & $12(18.5)$ & $18(27.7)$ & $15(23.1)$ & $20(30.8)$ & & \\
\hline
\end{tabular}

HCC, hepatocellular carcinoma.

Table II. Expression of NF- $\kappa$ B protein in 65 cases of HCC and paracancerous tissues.

\begin{tabular}{|c|c|c|c|c|c|c|c|}
\hline \multirow[b]{2}{*}{ Group } & \multirow[b]{2}{*}{$\mathrm{n}(100 \%)$} & \multicolumn{6}{|c|}{ NF- $\kappa \mathrm{B}$ expression } \\
\hline & & - & + & ++ & +++ & $\chi^{2}$ & $\mathrm{P}$-value \\
\hline HCC tissues & 65 & $3(4.6)$ & $13(20.0)$ & $17(26.2)$ & $32(49.2)$ & 25.966 & $<0.001$ \\
\hline Paracancerous tissue & 65 & $3(4.6)$ & $28(43.1)$ & $28(43.1)$ & $6(9.2)$ & & \\
\hline
\end{tabular}

HCC, hepatocellular carcinoma.
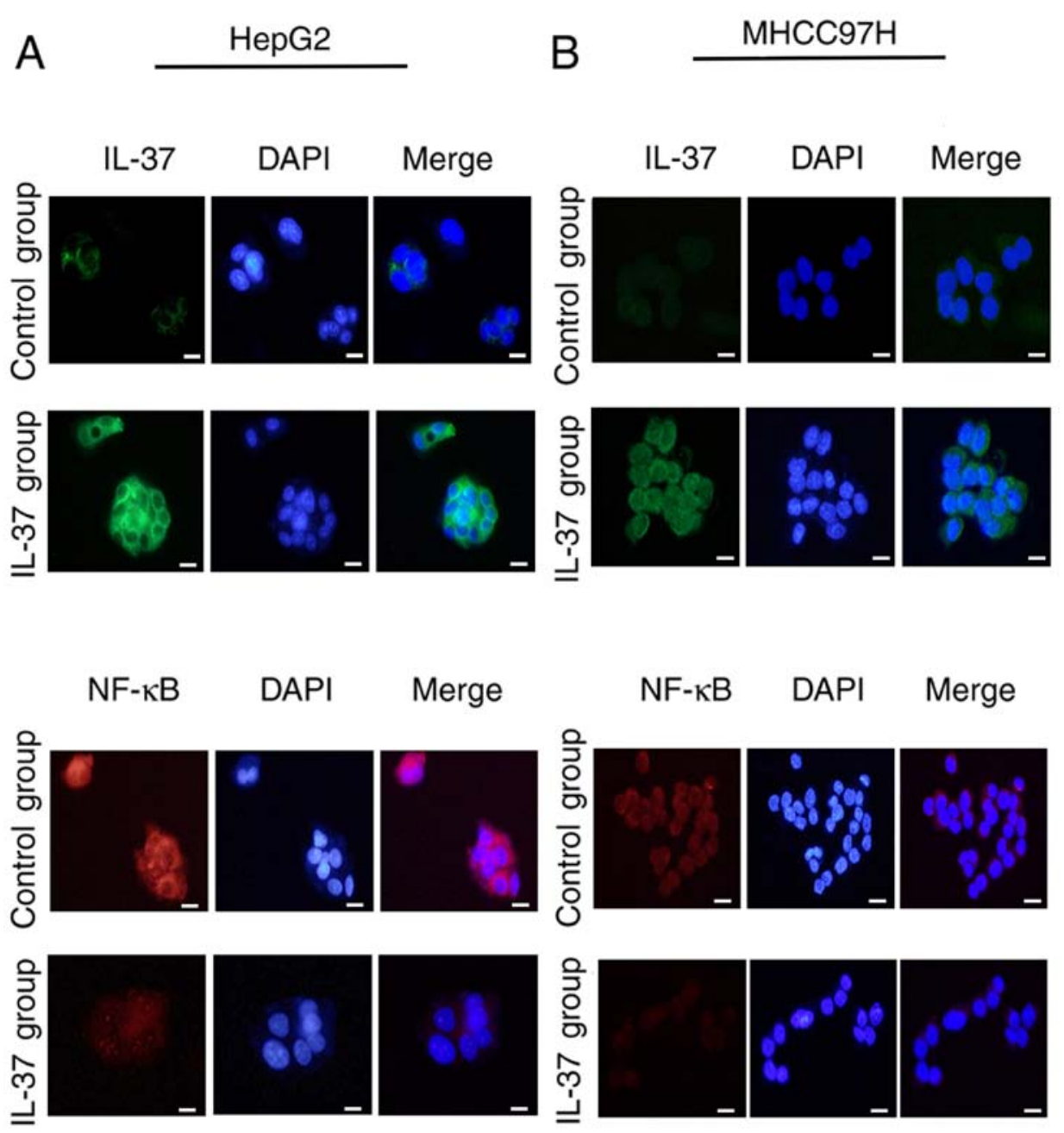

Figure 2. Gene transfection of IL-37 in two liver cancer cell lines changes the protein expression of IL-37 and NF- $\mathrm{KB}$ through immunofluorescence staining. (A) Immunofluorescence staining for IL-37 and NF- $\mathrm{B}$ in HepG2 cells. (B) Immunofluorescence staining for IL-37 and NF- $\mathrm{kB}$ in MHCC $97 \mathrm{H}$ cells. Magnification, x40. Scale bar, $10 \mu \mathrm{m}$. IL-37 group, cells transfected with IL-37 overexpressing plasmid pEZ-M02-IL-37; Control group, cells transfected with the control plasmid, pEZ-M02. 
Table III. Association between the expression of IL-37 protein and clinicopathological parameters in 65 cases of HCC tissues.

\begin{tabular}{|c|c|c|c|c|c|c|}
\hline \multirow[b]{2}{*}{ Group } & \multicolumn{6}{|c|}{ IL-37 expression } \\
\hline & $\mathrm{n}(100 \%)$ & - & + & +++ & $\chi^{2}$ & P-value \\
\hline Age & & & & & 1.177 & 0.634 \\
\hline$\leq 55$ years & 49 & 39 (79.6) & $8(16.3)$ & $2(4.1)$ & & \\
\hline$>55$ years & 16 & $12(75.0)$ & $4(25.0)$ & $0(0.0)$ & & \\
\hline Sex & & & & & 2.259 & 0.357 \\
\hline Male & 51 & $38(74.5)$ & $11(21.6)$ & $2(3.9)$ & & \\
\hline Female & 14 & $13(92.9)$ & $1(7.1)$ & $0(0.0)$ & & \\
\hline Tumor size & & & & & 1.548 & 0.434 \\
\hline$\leq 2 \mathrm{~cm}$ & 17 & $15(88.2)$ & $2(11.8)$ & $0(0.0)$ & & \\
\hline$>2 \mathrm{~cm}$ & 48 & $36(75.0)$ & $10(20.8)$ & $2(4.2)$ & & \\
\hline Serum AFP & & & & & 6.522 & 0.039 \\
\hline$\leq 8.1 \mathrm{ng} / \mathrm{ml}$ & 17 & $11(64.7)$ & $4(23.5)$ & $2(11.8)$ & & \\
\hline$>8.1 \mathrm{ng} / \mathrm{ml}$ & 48 & $40(83.3)$ & $8(16.7)$ & $0(0.0)$ & & \\
\hline HBsAg & & & & & 1.37 & 0.624 \\
\hline Negative & 12 & $9(75.0)$ & $2(16.7)$ & $1(8.3)$ & & \\
\hline Positive & 53 & $42(79.2)$ & $10(18.9)$ & $1(1.9)$ & & \\
\hline Histological differentiation & & & & & 1.978 & 0.719 \\
\hline Well & 16 & $13(81.3)$ & $3(18.8)$ & $0(0.0)$ & & \\
\hline Moderate $^{\mathrm{a}}$ & 43 & $34(79.1)$ & $7(16.3)$ & $2(4.7)$ & & \\
\hline Poor & 6 & $4(66.7)$ & $2(33.3)$ & $0(0.0)$ & & \\
\hline BCLC stage & & & & & 3.174 & 0.28 \\
\hline A & 26 & $19(73.1)$ & $7(26.9)$ & $0(0.0)$ & & \\
\hline $\mathrm{B} \& \mathrm{C}$ & 39 & $32(82.1)$ & $5(12.8)$ & $2(5.1)$ & & \\
\hline Liver cirrhosis & & & & & 2.928 & 0.331 \\
\hline Absence & 38 & $31(81.6)$ & $5(13.2)$ & $2(5.3)$ & & \\
\hline Presence & 27 & $20(74.1)$ & $7(25.9)$ & $0(0.0)$ & & \\
\hline Vascular infiltration & & & & & 1.112 & 0.659 \\
\hline Negative & 59 & 47 (79.6) & $10(16.9)$ & $2(3.4)$ & & \\
\hline Positive & 6 & $4(66.7)$ & $2(33.3)$ & $0(0.0)$ & & \\
\hline
\end{tabular}

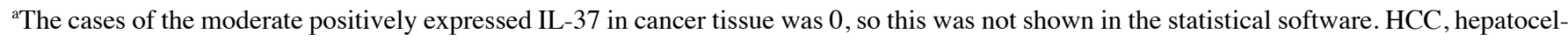
lular carcinoma; BCLC, Barcelona Clinic liver cancer; HBsAg, hepatitis B surface antigen; AFP, $\alpha$-fetoprotein.

of positive staining and the percentage of positive cells. The intensity of positive staining was: Score of 0 , no coloring; score of 1, pale yellow; score of 2, brown-yellow; score of 3 , tan. The percentage of positive cells was: Score of 1 , the percentage of positive cells $<30 \%$; score of 2 , the percentage of positive cells $\leq 30-60 \%$; score of 3 , the percentage of positive cells $>60 \%$. The final results were determined by the sum of the scores of the intensity of positive staining and percentage of positive cells: Score of 0 , negative (-); score of 2-3, weakly positive $(+)$; score of $4-5$, moderately positive $(++)$ and score of 6 , strong positive $(+++)$.

Cell culture and gene transfection. Human liver cancer cells were cultured in Dulbecco's modified Eagle's medium(DMEM; Gibco; Thermo Fisher Scientific, Inc.) supplemented with $10 \%$ fetal bovine serum (lot no . D213FD0254; BBI Life Sciences
Corporation), $100 \mathrm{mg} / \mathrm{ml}$ penicillin and $100 \mathrm{U} / \mathrm{ml}$ streptomycin, and cultured in a wet incubator containing $5 \% \mathrm{CO}_{2}$ at $37^{\circ} \mathrm{C}$. For gene transfection, pEZ-M02 or pEZ-M02-IL-37 vector was transfected into cells by Lipofectamine 3000. PEZ-M02 was an empty vector and used as the control plasmid for transfection. A total of $5 \times 10^{5}$ cells were transfected with $1.5 \mu \mathrm{l} / \mathrm{ml}$ Lipofectamine 3000 and $3 \mu \mathrm{l} / \mathrm{ml}$ auxiliary reagent (Invitrogen; Thermo Fisher Scientific, Inc.; cat. no. L3000015), and $1.5 \mu \mathrm{g} / \mathrm{ml}$ plasmid. Cells were subsequently cultured for $48 \mathrm{~h}$ and harvested for immunofluorescence (IF) and western blot analyses.

IF. HepG2 and MHCC97H cells were seeded on cover glass $\left(5 \times 10^{4}\right.$ cells/slide) previously sterilized $\left(121^{\circ} \mathrm{C}, 0.12 \mathrm{MPa}\right.$, $30 \mathrm{~min}$ ) and soaked in $1 \mathrm{x}$ poly-L-lysine for $10 \mathrm{~min}$. After 2 days, the cells were fixed with $100 \%$ methanol for 5 min 
Table IV. Association between the expression of IL-37 protein and clinicopathological parameters in 65 cases of paracancerous tissues.

\begin{tabular}{|c|c|c|c|c|c|c|c|}
\hline \multirow[b]{2}{*}{ Group } & \multicolumn{7}{|c|}{ IL-37 expression } \\
\hline & $\mathrm{N}(100 \%)$ & - & + & ++ & +++ & $\chi^{2}$ & P-value \\
\hline Age & & & & & & 6.29 & $<0.999$ \\
\hline$\leq 55$ years & 49 & $6(12.2)$ & $13(26.5)$ & $13(26.5)$ & $17(34.7)$ & & \\
\hline$>55$ years & 16 & $6(37.5)$ & $5(31.3)$ & $2(12.5)$ & $3(18.8)$ & & \\
\hline Sex & & & & & & 13.12 & 0.003 \\
\hline Male & 51 & $11(21.6)$ & $9(17.6)$ & $12(23.5)$ & $19(37.3)$ & & \\
\hline Female & 14 & $1(7.1)$ & $9(64.3)$ & $3(21.4)$ & $1(7.1)$ & & \\
\hline Tumor size & & & & & & 7.996 & 0.045 \\
\hline$\leq 2 \mathrm{~cm}$ & 16 & $0(0.0)$ & $8(50.0)$ & $4(25.0)$ & $4(25.0)$ & & \\
\hline$>2 \mathrm{~cm}$ & 49 & $12(24.5)$ & $10(20.4)$ & $11(22.4)$ & $16(32.7)$ & & \\
\hline Serum AFP & & & & & & 1.257 & 0.774 \\
\hline$\leq 8.1 \mathrm{ng} / \mathrm{ml}$ & 17 & $2(11.8)$ & $4(23.5)$ & $5(29.4)$ & $6(35.3)$ & & \\
\hline$>8.1 \mathrm{ng} / \mathrm{ml}$ & 48 & $10(20.8)$ & $14(29.2)$ & $10(20.8)$ & $14(29.2)$ & & \\
\hline HBsAg & & & & & & 0.894 & 0.873 \\
\hline Negative & 12 & $2(16.7)$ & $3(25.0)$ & $2(16.7)$ & $5(41.7)$ & & \\
\hline Positive & 53 & $10(18.9)$ & $15(28.3)$ & $13(24.5)$ & $15(28.3)$ & & \\
\hline Histological differentiation & & & & & & 1.829 & 0.949 \\
\hline Well & 16 & $3(18.8)$ & $5(31.3)$ & $3(18.8)$ & $5(31.3)$ & & \\
\hline Moderate & 43 & $7(16.3)$ & $11(25.6)$ & $11(25.6)$ & $14(32.6)$ & & \\
\hline Poor & 6 & $2(33.3)$ & $2(33.3)$ & $1(16.7)$ & $1(16.7)$ & & \\
\hline BCLC stage & & & & & & 3.681 & 0.319 \\
\hline A & 26 & $2(7.7)$ & $9(34.6)$ & $6(23.1)$ & $9(34.6)$ & & \\
\hline $\mathrm{B} \& \mathrm{C}$ & 39 & $10(25.6)$ & $9(23.1)$ & $9(23.1)$ & $11(28.2)$ & & \\
\hline Liver cirrhosis & & & & & & 1.881 & 0.637 \\
\hline Absence & 38 & $6(15.8)$ & $10(26.3)$ & $11(28.9)$ & $11(28.9)$ & & \\
\hline Presence & 27 & $6(22.2)$ & $8(29.6)$ & $4(14.8)$ & $9(33.3)$ & & \\
\hline Vascular infiltration & & & & & & 1.612 & 0.715 \\
\hline Negative & 59 & $12(20.3)$ & $16(27.1)$ & $13(22.0)$ & $18(30.5)$ & & \\
\hline Positive & 6 & $0(0.0)$ & $2(33.3)$ & $2(33.3)$ & $2(33.3)$ & & \\
\hline
\end{tabular}

HCC, hepatocellular carcinoma; BCLC, Barcelona Clinic liver cancer; HBsAg, hepatitis B surface antigen; AFP, $\alpha$-fetoprotein.

at room temperature. Then the cells were permeabilized with Triton X-100 for $10 \mathrm{~min}$ at room temperature and blocked in the animal non-immune serum [reagent B, UltraSensitive ${ }^{\mathrm{TM}}$ SP (Mouse/Rabbit) IHC Kit from MXB Biotechnologies] for $1 \mathrm{~h}$ at room temperature. The cells were incubated with the primary antibodies against IL-37 (1:100) and NF- $\mathrm{B}(1: 100)$ at $37^{\circ} \mathrm{C}$ for $1 \mathrm{~h}$. Finally, cells were washed three times with PBS and stained with Dylight 594-conjugated secondary antibody (1:100; cat. no. A23420; Abbkine Scientific Co., Ltd.) for $1 \mathrm{~h}$. Images were analyzed under a fluorescence microscope (magnification $\mathrm{x} 40$ ). Staining intensity was calculated using ImageJ software (version 1.52p; National Institutes of Health).

Western blot analysis. HepG2 and MHCC97H cells were lysed in RIPA buffer (cat. no. P0013C; Beyotime Institute of Biotechnology) on ice, collected into tubes and centrifuged at $12,000 \mathrm{x} \mathrm{g}$ for $20 \mathrm{~min}$ at $4^{\circ} \mathrm{C}$. The supernatants were then boiled and protein concentrations were determined using a BCA assay. An equal amount of protein (200 $\mu \mathrm{g}$ per lane) was separated via SDS-PAGE (10\% gel) and transferred onto PVDF membranes. Membranes were blocked in PBS containing 5\% powdered milk and $0.05 \%$ Tween 20 for $1 \mathrm{~h}$ at $25^{\circ} \mathrm{C}$. Membranes were then incubated overnight at $4^{\circ} \mathrm{C}$ with antibodies against IL-37 (1:500), NF- $\kappa$ B (1:1,000), and GAPDH (1:500). After being washed wish PBST, the membranes were incubated with goat anti-rabbit horseradish peroxidase-conjugated secondary antibody (1:1,000; cat. no. A0208; Beyotime Institute of Biotechnology) for $1 \mathrm{~h}$ and visualized using ECL kit under the Amersham Imager 600 automated chemiluminescence image analysis system (Roche Diagnostics). The amount of target protein was calculated by gray scanning using Image $\mathbf{J}$ software (version 1.52p, National Institutes of Health). 
Table V. Association between the expression of NF- $\mathrm{KB}$ protein and clinicopathological parameters in 65 cases of $\mathrm{HCC}$ tissues.

\begin{tabular}{|c|c|c|c|c|c|c|c|}
\hline \multirow[b]{2}{*}{ Group } & \multicolumn{7}{|c|}{$\mathrm{NF}-\kappa \mathrm{B}$ expression } \\
\hline & $\mathrm{N}(100 \%)$ & - & + & ++ & +++ & $\chi^{2}$ & $\mathrm{P}$-value \\
\hline Age & & & & & & 3.071 & 0.389 \\
\hline$\leq 55$ years & 49 & $2(4.1)$ & $8(16.30)$ & $12(24.5)$ & $27(55.1)$ & & \\
\hline$>55$ years & 16 & $1(6.3)$ & $5(31.3)$ & $5(31.3)$ & $5(31.3)$ & & \\
\hline Sex & & & & & & 0.452 & 0.968 \\
\hline Male & 51 & $2(3.9)$ & $10(19.6)$ & $13(25.5)$ & $26(51.0)$ & & \\
\hline Female & 14 & $1(7.1)$ & $3(21.4)$ & $4(28.6)$ & $6(42.9)$ & & \\
\hline Tumor size & & & & & & 4.383 & 0.226 \\
\hline$\leq 2 \mathrm{~cm}$ & 17 & $1(5.9)$ & $1(5.9)$ & $7(41.2)$ & $8(47.1)$ & & \\
\hline$>2 \mathrm{~cm}$ & 48 & $2(4.2)$ & $12(25.0)$ & $10(20.8)$ & $24(50.0)$ & & \\
\hline Serum AFP & & & & & & 1.352 & 0.727 \\
\hline$\leq 8.1 \mathrm{ng} / \mathrm{ml}$ & 17 & $1(5.9)$ & $2(11.8)$ & $4(23.5)$ & $10(58.8)$ & & \\
\hline$>8.1 \mathrm{ng} / \mathrm{ml}$ & 48 & $2(4.2)$ & $11(22.9)$ & $13(27.1)$ & $22(45.8)$ & & \\
\hline HBsAg & & & & & & 2.496 & 0.48 \\
\hline Negative & 12 & $0(0.0)$ & $4(33.3)$ & $2(16.7)$ & $6(50.0)$ & & \\
\hline Positive & 53 & $3(5.7)$ & $9(17.0)$ & $15(28.3)$ & $26(49.1)$ & & \\
\hline Histological differentiation & & & & & & 4.875 & 0.584 \\
\hline Well & 16 & $0(0.0)$ & $3(18.8)$ & $5(31.3)$ & $8(50.0)$ & & \\
\hline Moderate & 43 & $2(4.7)$ & $10(23.3)$ & $11(25.6)$ & $20(46.5)$ & & \\
\hline Poor & 6 & $1(16.7)$ & $0(0.0)$ & $1(16.7)$ & $4(66.7)$ & & \\
\hline BCLC stage & & & & & & 2.147 & 0.593 \\
\hline A & 26 & $1(3.8)$ & $3(11.5)$ & $8(30.8)$ & $14(53.8)$ & & \\
\hline $\mathrm{B} \& \mathrm{C}$ & 39 & $2(5.1)$ & $10(25.6)$ & $9(23.1)$ & $18(46.2)$ & & \\
\hline Liver cirrhosis & & & & & & 1.168 & 0.788 \\
\hline Absence & 38 & $1(2.6)$ & $8(21.1)$ & $11(28.9)$ & $18(47.4)$ & & \\
\hline Presence & 27 & $2(7.4)$ & $5(18.5)$ & $6(22.2)$ & $18(46.2)$ & & \\
\hline Vascular infiltration & & & & & & 0.473 & 1 \\
\hline Negative & 59 & $3(5.1)$ & $12(20.3)$ & $15(25.4)$ & $29(49.2)$ & & \\
\hline Positive & 6 & $0(0.0)$ & $1(16.7)$ & $2(33.3)$ & $3(50.0)$ & & \\
\hline
\end{tabular}

HCC, hepatocellular carcinoma; BCLC, Barcelona Clinic liver cancer; HBsAg, hepatitis B surface antigen; AFP, $\alpha$-fetoprotein.

Statistical analysis. The results were analyzed using SPSS software (version 19.0; SPSS, Inc.) and expressed as the mean \pm standard deviation. The differences were compared by $\chi^{2}$ test, student's t-test or Spearman correlation. $\mathrm{P}<0.001$, $\mathrm{P}<0.01$ or $\mathrm{P}<0.05$ were considered to indicate statistically significant difference.

\section{Results}

Protein expression of $I L-37$ and $N F-\kappa B$ in HCC and PT. In HCC, IL-37 protein expression was at a low level with weak positive staining (Fig. 1A). The positive rate was $21.5 \%(14 / 65)$. In PT, the moderately positive staining of IL-37 protein was $27.7 \%(18 / 65)$, and the strongly positive was $30.8 \%(20 / 65)$ (Fig. 1B). The positive rate was $81.5 \%(53 / 65)$. There was a significant difference in the expression of IL-37 between HCC and PT $\left(\chi^{2}=55.05, \mathrm{P}<0.001\right.$; Table I $)$.
For NF- $\kappa \mathrm{B}$ expression, strong positive expression in HCC tissues (Fig. 1C) and weak positive expression in PT (Fig. 1D) was observed. $\mathrm{NF}-\kappa \mathrm{B}$ protein expression was observed in the cytoplasm and nucleus. Notably, the expression rate of $\mathrm{NF}-\kappa \mathrm{B}$ protein in both HCC and PT was 95.4\% (62/65). However, the positive intensity of $\mathrm{NF}-\kappa \mathrm{B}$ in $\mathrm{HCC}$ tissues was significantly different from that in PT $\left(\chi^{2}=25.966, \mathrm{P}<0.001\right.$; Table II $)$

Gene transfection of IL-37 in liver cancer cell lines increases the protein expression of IL-37 and decreases $N F-\kappa B$ through IF staining. In order to assess whether the protein expression levels of liver cancer cell lines was similar to that of the HCC tissues, IF was performed in the present

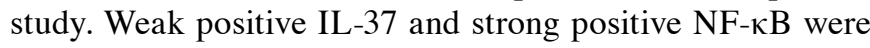
observed in both of the two cell lines (Fig. 2), which was consistent with that of the IHC results. Furthermore, plasmids overexpressing IL-37 were constructed and transfected 
Table VI. Association between the expression of NF- $\kappa \mathrm{B}$ protein and clinicopathological parameters in paracancerous tissues.

\begin{tabular}{|c|c|c|c|c|c|c|c|}
\hline \multirow[b]{2}{*}{ Group } & \multicolumn{7}{|c|}{$\mathrm{NF}-\kappa \mathrm{B}$ expression } \\
\hline & $\mathrm{N}(100 \%)$ & - & + & ++ & +++ & $\chi^{2}$ & P-value \\
\hline Age & & & & & & 14.9 & 0.002 \\
\hline$\leq 55$ years & 49 & $0(0.0)$ & 19 (38.8) & $26(53.1)$ & $4(8.2)$ & & \\
\hline$>55$ years & 16 & $3(18.8)$ & $9(56.3)$ & $2(12.5)$ & $2(12.5)$ & & \\
\hline Sex & & & & & & 13.15 & 0.006 \\
\hline Male & 51 & $0(0.0)$ & $25(49.0)$ & $21(41.2)$ & $5(9.8)$ & & \\
\hline Female & 14 & $3(21.4)$ & $3(21.4)$ & $7(50.0)$ & $1(7.1)$ & & \\
\hline Tumor size & & & & & & 5.703 & 0.126 \\
\hline$\leq 2 \mathrm{~cm}$ & 17 & $1(5.9)$ & $11(64.7)$ & $5(29.4)$ & $0(0.0)$ & & \\
\hline$>2 \mathrm{~cm}$ & 48 & $2(4.2)$ & $17(35.4)$ & $23(47.9)$ & $6(12.5)$ & & \\
\hline Serum AFP & & & & & & 5.703 & 0.126 \\
\hline$\leq 8.1 \mathrm{ng} / \mathrm{ml}$ & 17 & 0 & $8(47.1)$ & $6(35.3)$ & $3(17.6)$ & & \\
\hline$>8.1 \mathrm{ng} / \mathrm{ml}$ & 48 & $3(6.3)$ & $20(41.7)$ & $22(45.8)$ & $6(12.5)$ & & \\
\hline HBsAg & & & & & & 0.863 & 0.957 \\
\hline Negative & 12 & 0 & $6(50.0)$ & $5(41.7)$ & $1(8.3)$ & & \\
\hline Positive & 53 & $3(5.7)$ & $22(41.5)$ & $23(43.4)$ & $5(9.4)$ & & \\
\hline Histological differentiation & & & & & & 5.779 & 0.439 \\
\hline Well & 16 & $0(0.0)$ & $9(56.3)$ & $7(43.8)$ & $0(0.0)$ & & \\
\hline Moderate & 43 & $2(4.7)$ & $17(39.5)$ & $19(44.2)$ & $5(11.6)$ & & \\
\hline Poor & 6 & $1(16.7)$ & $2(33.3)$ & $2(33.3)$ & $1(16.7)$ & & \\
\hline BCLC stage & & & & & & 9.048 & 0.02 \\
\hline A & 26 & $1(3.8)$ & $17(65.4)$ & 7 (26.9) & $1(3.8)$ & & \\
\hline $\mathrm{B} \& \mathrm{C}$ & 39 & $2(5.1)$ & $11(28.2)$ & $21(53.8)$ & $5(12.8)$ & & \\
\hline Liver cirrhosis & & & & & & 0.584 & 0.917 \\
\hline Absence & 38 & $2(5.3)$ & $15(39.5)$ & $17(44.7)$ & $4(10.5)$ & & \\
\hline Presence & 27 & $1(3.7)$ & $13(48.1)$ & $11(40.7)$ & $2(7.4)$ & & \\
\hline Vascular infiltration & & & & & & 2.909 & 0.388 \\
\hline Negative & 59 & $2(3.4)$ & $26(44.1)$ & $25(42.4)$ & $6(10.2)$ & & \\
\hline Positive & 6 & $1(16.7)$ & $2(33.3)$ & $3(50.0)$ & 0 & & \\
\hline
\end{tabular}

HCC, hepatocellular carcinoma; BCLC, Barcelona Clinic liver cancer; HBsAg, hepatitis B surface antigen; AFP, $\alpha$-fetoprotein.

into HepG2 (Fig. 2A) and MHCC97H cells (Fig. 2B). The results revealed that the fluorescence intensity of IL-37 was significantly increased and higher than that in the control group (Fig. 2A and B). The fluorescence intensity of NF- $\kappa \mathrm{B}$ was markedly decreased by IL-37 expression, indicating that IL-37 inhibited the protein expression of NF- $\kappa \mathrm{B}$ in both of the two cell lines (Fig. 2A and B).

Association between expression of IL-37 protein and clinical indexes in HCC and PT. The expression of IL-37 protein in $\mathrm{HCC}$ was associated with serum $\operatorname{AFP}\left(\chi^{2}=6.522, \mathrm{P}=0.039\right)$ but not with other clinicopathological features ( $\mathrm{P}>0.05$; Table III). In AFP-negative $\mathrm{HCC}$, the weak positive and strong positive expression rates of IL-37 protein were $23.5 \%$ (4/17) and $11.8 \%$ (2/17), respectively. In AFP-positive HCC, IL-37 expression was only weakly positive, with a positive rate of $16.7 \%(8 / 48)$. The expression of IL-37 protein in the PT was associated with the sex of the individual $\left(\chi^{2}=13.12, \mathrm{P}=0.003\right)$ and tumor size
Table VII. Correlation between the protein expression of IL-37 and $\mathrm{NF}-\kappa \mathrm{B}$ in $\mathrm{HCC}$ tissues.

\begin{tabular}{|c|c|c|c|c|c|}
\hline \multirow[b]{2}{*}{ IL-37 } & \multirow[b]{2}{*}{ n $(100 \%)$} & \multicolumn{4}{|c|}{$N F-\kappa B$} \\
\hline & & - & + & ++ & +++ \\
\hline - & 51 & 3 & 8 & 8 & 32 \\
\hline+ & 12 & 0 & 5 & 7 & 0 \\
\hline $\begin{array}{l}+++ \\
r=-0.277\end{array}$ & $\begin{array}{c}2 \\
\mathrm{P}=0.029\end{array}$ & 0 & 0 & 2 & 0 \\
\hline
\end{tabular}

HCC, hepatocellular carcinoma.

$\left(\chi^{2}=7.996, \mathrm{P}=0.045\right)$ but not with other clinicopathological features (Table IV). 
A

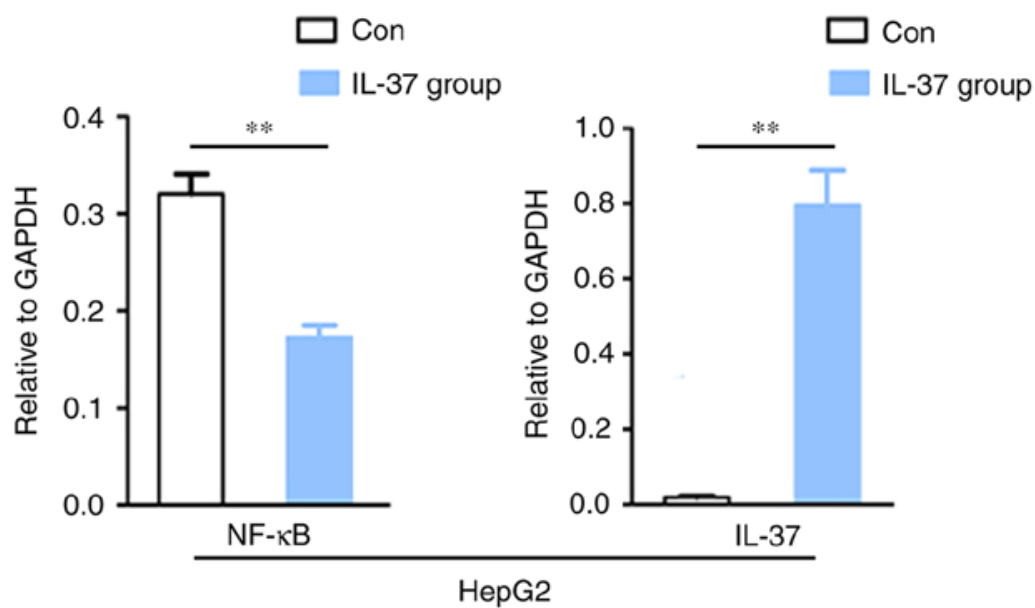

B

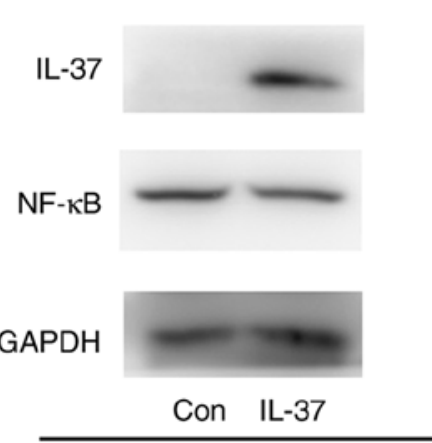

HepG2

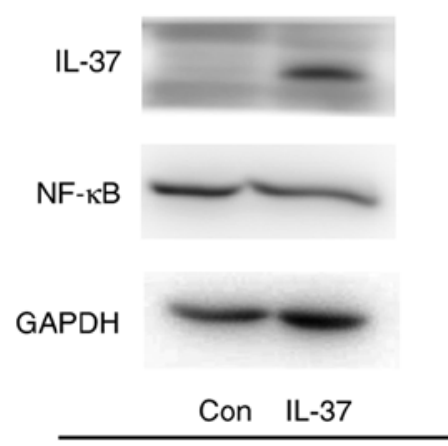

$\mathrm{MHCC} 97 \mathrm{H}$

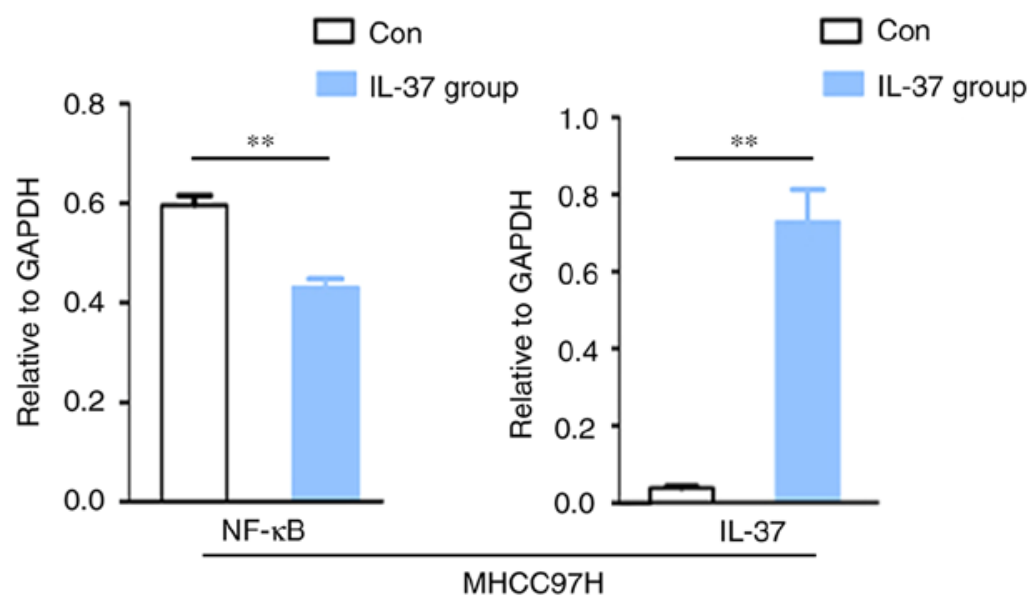

Figure 3. Overexpression of IL-37 inhibits NF-кB protein expression in the liver cancer cell lines by western blotting. (A) Western blot analysis of IL-37 and

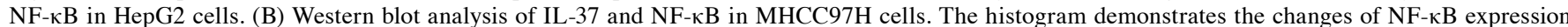
relative to GAPDH. IL-37 group, cells transfected with IL-37 over-expressing plasmid pEZ-M02-IL-37; Control group, cells that transfected with the control plasmid, pEZ-M02. ${ }^{* *} \mathrm{P}<0.01$

Association between $N F-\kappa B$ expression and clinical indexes in HCC and PT. In HCC, there was no association between the expression of NF- $\mathrm{\kappa B}$ protein and the clinicopathological features of patients with HCC ( $>>0.05$; Table V). In PT, the expression of NF- $\mathrm{kB}$ protein in $\mathrm{PT}$ was associated with age $\left(\chi^{2}=14.9, \mathrm{P}=0.002\right)$, sex $\left(\chi^{2}=13.15, \mathrm{P}=0.006\right)$ and $\mathrm{BCLC}$ stage, which is a clinical staging system for liver cancer (22) $\left(\chi^{2}=9.048 ; \mathrm{P}=0.02 ;\right.$ Table VI $)$.

Correlation between the protein expression of IL-37 and $N F-\kappa B$ in $H C C$ and $P T$. The results of the present study demonstrated that there was a correlation between the protein expression of IL-37 and NF- $\kappa \mathrm{B}$ in HCC ( $\mathrm{r}=-0.277, \mathrm{P}=0.029)$, suggesting a negative correlation between the two genes (Table VII). However, there was no correlation between the protein expression of IL-37 and NF- $\mathrm{BB}$ in PT (P>0.05, data not shown).

Overexpression of IL-37 inhibited $N F-\kappa B$ protein expression in liver cancer cell lines. In order to further verify whether IL-37 modulates the protein expression of NF-kB in liver cancer cells, gene transfection of IL-37 and western blot analysis was performed. Herein, IL-37 gene transfection upregulated IL-37 protein expression in HepG2 and MHCC97H cells (Fig. 3).
Overexpression of IL-37 inhibited NF- $\mathrm{\kappa B}$ protein expression by $56.50 \%$ in HepG2 cells $(\mathrm{P}<0.05$; Fig. $3 \mathrm{~A})$ and $30.52 \%$ in MHCC 97H cells $(\mathrm{P}<0.05$; Fig. 3B).

\section{Discussion}

HBV infection involves the infection of the virus itself and a series of pathological reactions induced by HBV (2). The present study indicated that there is no significant association between IL-37 and HBV (HBsAg positive), but IL-37 may be associated with HBV infection-induced immune responses through NF-kB. HBV infection could trigger a rapid innate immune response through NF- $\kappa \mathrm{B}$ (23). The present study demonstrated that IL-37 protein expression downregulated NF-kB protein expression, indicating that IL-37 may play an inhibitory role in HBV infection-induced immune responses through inhibition of NF-kB. This hypothesis requires further research in the future and was not the primary focus of the present study. The present study mainly focused on the protein expression IL-37 in HCC, and the results did provide new clues for understanding the development of HCC.

The present study revealed a low expression of IL-37 in HCC, which was negatively associated with serum AFP. 
IL-37 expression is at a very low level in normal tissues and increases markedly as a response to the inflammatory stimulation. The expression of IL-37 is also very low in cancer tissues, such as colorectal cancer (24) and non-small cell lung cancer (25). The results of the present study demonstrated that IL-37 expression was high in PT cells and markedly decreased in liver cancer cells. Notably, the present study revealed a negative association between serum AFP and IL-37 of cancer tissues, but not in PT. AFP usually increases with the deterioration of hepatocellular carcinogenesis and is a relatively specific clinical index for the diagnosis of primary liver cancer, but the specificity and sensitivity of diagnosis are relatively low (26). Some researchers have tried to combine AFP detection with some interleukin detection for the diagnosis and prognosis of liver cancer (27). In the present study, serum AFP was revealed to be specifically associated with IL-37 of cancerous tissues, but not PT. This phenomenon indicated that combining the detection of AFP and cancerous IL-37 may improve the sensitivity and accuracy for the diagnosis and prognostic judgment of liver cancer.

There were 59 cases $(59 / 65)$ that were associated with $\mathrm{HBV}$, hepatitis $\mathrm{C}$ virus or non-alcoholic steatohepatitis in those 65 specimens. The results revealed that there was no statistical difference in IL-37 expression (data not shown). In addition, due to strict ethical requirements, it is often difficult to collect large amounts of human tissues. In the present study, the Pathology Department of Foshan First People's Hospital provided 65 specimens, and no wax tissues. There were two slices of each specimen provided. Larger sample sizes are required in order to further investigate the role of IL-37 and the associated mechanisms in liver cancer.

There was a significant difference between the NF- $\kappa \mathrm{B}$ protein expression in cancer tissues and PT. The expression rate of $\mathrm{NF}-\kappa \mathrm{B}$ in cancer tissues was markedly increased compared with that in PT. This was consistent with that in a variety of tumors, such as colorectal cancer, gastric cancer, prostate cancer and liver cancer, in previous studies (28).

Furthermore, the correlation between IL-37 and NF- $\kappa \mathrm{B}$ expression in $\mathrm{HCC}$ tissues was unclear before, and therefore analyzed in the present study. $\mathrm{NF}-\kappa \mathrm{B}$ expression was negatively correlated with IL-37 expression in cancer tissues but not in PT. Here, if was demonstrated that the decrease of IL-37 can increase inflammation, and the increase of NF- $\kappa \mathrm{B}$ can directly promote the release and activation of inflammatory factors. These abnormal changes may form positive feedback to promote the controllable inflammation into uncontrollable inflammation, and finally caused the malignant transformation of normal cells and the occurrence of tumor.

In conclusion, IL-37 expression was negatively correlated with $\mathrm{NF}-\kappa \mathrm{B}$ expression in both $\mathrm{HCC}$ tissue and liver cancer cell lines. IL-37 may play a role in the development of liver cancer.

\section{Acknowledgements}

The authors would like to thank Dr Haiyan Shi (Pathology Department, Foshan First People's Hospital) who helped to collect the specimens and provided the ethics certificate in her hospital.

\section{Funding}

The present study was funded by the Science and Technology Plan Project of Guangdong Province (grant no. 2016A020215147), the Natural Science Foundation of Guangdong Province, China (grant no. 2018A030307026), the Medical Science and Technology Research Fund of Guangdong province (grant no. A2017605), and the National Natural Science Foundation of China (grant no. 81302244).

\section{Availability of data and materials}

The datasets used and/or analyzed during the present study are available from the corresponding author on reasonable request.

\section{Authors' contributions}

SW and PL wrote the manuscript and were responsible for the examination and analysis. KW, LS, GZ and HG assisted with the statistical analysis. KH, RL, ZD, SL, PO, YW and ZC performed the experiments. All authors read and approved the final manuscript.

\section{Ethics approval and consent to participate}

The study was approved by the Ethics Committee of The First People's Hospital of Foshan (Foshan, China).

\section{Patient consent for publication}

Not applicable.

\section{Competing interests}

The authors declare that they have no competing interests.

\section{References}

1. Wong MC, Jiang JY, Goggins WB, Liang M, Fang Y, Fung FD, Leung C, Wang HH, Wong GL, Wong VW and Chan HL: International incidence and mortality trends of liver cancer: A global profile. Sci Rep 7: 45846, 2017.

2. Cheuk-Fung Yip T, Wai-Sun Wong V, Lik-Yuen Chan H, Tse YK, Pik-Shan Kong A, Long-Yan Lam K, Chung-Yan Lui G and Lai-Hung Wong G: Effects of diabetes and glycemic control on risk of hepatocellular carcinoma after seroclearance of hepatitis B surface antigen. Clin Gastroenterol Hepatol 16: 765-773, 2018.

3. Saha Turna N and Wu F: Risk assessment of aflatoxin-related liver cancer in Bangladesh. Food Additi Contam Part A Chem Anal Control Expo Risk Assess 36: 320-326, 2019.

4. Kawamura Y, Arase Y, Ikeda K, Akuta N, Kobayashi M, Saitoh S Suzuki F, Suzuki Y, Inao M, Mochida S and Kumada H: Effects of alcohol consumption on hepatocarcinogenesis in Japanese patients with fatty liver disease. Clin Gastroenterol Hepatol 14: 597-605, 2016.

5. Taniguchi $\mathrm{K}$ and Karin $\mathrm{M}$ : NF- $\mathrm{\kappa B}$, inflammation, immunity and cancer: Coming of age. Nat Rev Immunol 18: 309-324, 2018.

6. Banchereau J, Pascual V and O'garra A: From IL-2 to IL-37: The expanding spectrum of anti-inflammatory cytokines. Nat Immunol 13: 925-931, 2012.

7. Wang WQ, Dong K, Zhou L, Jiao GH, Zhu CZ, Li WW, Yu G, Wu WT, Chen S, Sun ZN, et al: IL-37b gene transfer enhances the therapeutic efficacy of mesenchumal stromal cells in DSS-induced colitis mice. Acta Pharm Sin 36: 1377-1387, 2015.

8. Wang L, Wang Y, Xia L, Shen H and Lu J: Elevated frequency of IL-37-and IL-18R $\alpha$-positive T cells in the peripheral blood of rheumatoid arthritis patients. Cytokine 110: 291-297, 2018. 
9. Wang J, Shen Y, Li C, Liu C, Wang ZH, Li YS, Ke X and Hu GH: IL-37 attenuates allergic process via STAT6/STAT3 pathways in murine allergic rhinitis. Int Immunopharmacol 69: 27-33, 2019.

10. de Sousa JR, Prudente RL, Dias Junior LB, Oliveira Carneiro FR Sotto MN and Simoes Quaresma JA: IL-37 and leprosy: A nove cytokine involved in the host response to mycobacterium leprae infection. Cytokine 106: 89-94, 2018.

11. Ye L, Ji L, Wen Z, Zhou Y, Hu D, Li Y, Yu T, Chen B, Zhang J, Ding L, Du J and Huang Zet al: IL-37 inhibits the production of inflammatory cytokines in peripheral blood mononuclear cells of patients with systemic lupus erythematosus: Its correlation with disease activity. J Transl Med 12: 69, 2014.

12. Yang Y, Zhang ZX, Lian D, Haig A, Bhattacharjee RN and Jevnikar AM: IL-37 inhibits IL-18-induced tubular epithelial cell expression of pro-inflammatory cytokines and renal ischemia-reperfusion injury. Kidney Int 87: 396-408, 2015.

13. Bulau AM, Fink M, Maucksch C, Kappler R, Mayr D, Wagner K and Bufler P: In vivo expression of interleukin-37 reduces local and systemic inflammation in concanavalin A-induced hepatitis. ScientificWorldJournal 11: 2480-2490, 2011.

14. Feng XX, Chi G, Wang H, Gao Y, Chen Q, Ru YX, Luo ZL, Yan W, Li PY, Liu M, et al: IL-37 suppresses the sustained hepatic IFN- $\gamma / \mathrm{TNF}-\alpha$ production and $\mathrm{T}$ cell-dependent liver injury. Int Immunopharmacol 69: 184-193, 2019

15. Wang S, An W, Yao Y, Chen R, Zheng X, Yang W, Zhao Y, Hu X, Jiang E, Bie Y, et al: Interleukin 37 expression inhibits STAT3 to suppress the proliferation and invasion of human cervical cancer cells. J Cancer 6: 962-969, 2015.

16. Ouyang P, An W, Chen R, Zhang H, Chen D, Jiang E, Zhu W, Li P, Guo H, Chen Z and Wang S: IL-37 promotes cell apoptosis in cervical cancer involving bim upregulation. OncoTargets Ther 12: 2703-2712, 2019.

17. Jiang M, Wang Y, Zhang H, Ji Y, Zhao P, Sun R and Zhang C: IL-37 inhibits invasion and metastasis in non $\square$ small cell lung cancer by suppressing the IL-6/STAT3 signaling pathway. Thoracic Cancer 9: 621-629, 2018.

18. Wu T, Xu B, Zhao G, Luo J and Luo C: IL-37 suppresses migration and invasion of gallbladder cancer cells through inhibition of HIF-1 $\alpha$ induced epithelial-mesenchymal transition. Eur Rev Med Pharm Sci 22: 8179-8185, 2018.

19. Zhu B, Zhang P, Liu M, Jiang C, Liu H and Fu J: Prognostic significance of CSN2, CD8, and MMR status-associated nomograms in patients with colorectal cancer. Transl Oncol 11: $1202-1212,2018$.
20. Zhao JJ, Pan QZ, Pan K, Weng DS, Wang QJ, Li JJ, Lv L, Wang DD, Zheng HX, Jiang SS, et al: Interleukin-37 mediates the antitumor activity in hepatocellular carcinoma: Role for CD57+ NK cells. Sci Rep 4: 5177, 2014

21. Li P, Guo H, Zhou G, Shi H, Li Z, Guan X, Deng Z, Li S, Zhou S, Wang Y and Wang S: Increased ZNF84 expression in cervical cancer. Arch Gynecol Obstet 297: 1525-1532, 2018.

22. Chan AW, Kumada T, Toyoda H, Tada T, Chong CC, Mo FK, Yeo W, Johnson PJ, Lai PB, Chan AT, et al: Integration of albumin-bilirubin (ALBI) score into barcelona clinic liver cancer (BCLC) system for hepatocellular carcinoma. J Gastroenterol Hepatol 31: 1300-1306, 2016.

23. Yoneda M, Hyun J, Jakubski S, Saito S, Nakajima A, Schiff ER and Thomas E: Hepatitis B virus and DNA stimulation trigger a rapid innate immune response through NF- $\kappa$ B. J Immunol 197: 630-643, 2016

24. Yan X, Zhao J and Zhang R: Interleukin-37 mediates the antitumor activity in colon cancer through $\beta$-catenin suppression. Oncotarget 8: 49064, 2017.

25. Ge G, Wang A, Yang J, Chen Y, Yang J, Li Y and Xue Y: Interleukin-37 suppresses tumor growth through inhibition of angiogenesis in non-small cell lung cancer. J Exp Clin Cancer Res 35: 13, 2016.

26. Ma H, Sun X, Chen L, Cheng W, Han XX, Zhao B and He C: Multiplex immunochips for high-accuracy detection of AFP-L3\% based on surface-enhanced raman scattering: Implications for early liver cancer diagnosis. Anal Chem 89: 8877-8883, 2017.

27. Yang JY, Li X, Gao L, Teng ZH and Liu WC: Co-transfection of dendritic cells with AFP and IL-2 genes enhances the induction of tumor antigen-specific antitumor immunity. Exp Ther Med 4: 655-660, 2012

28. Xia Y, Shen S and Verma IM: NF- $\kappa B$, an active player in human cancers. Cancer Immunol Res 2: 823-830, 2014.

This work is licensed under a Creative Commons Attribution-NonCommercial-NoDerivatives 4.0 International (CC BY-NC-ND 4.0) License. 